\title{
La Suisse et le Fonds monétaire international : les intérêts en présence et le options politiques
}

Die Schweiz und der internationale Währungsfonds : Interessenlage und

Entwicklungspolitische optionen

\section{Richard Gerster}

\section{OpenEdition}

\section{Journals}

Édition électronique

URL : http://journals.openedition.org/aspd/1107

DOI : $10.4000 /$ aspd. 1107

ISSN : 1663-9669

Éditeur

Institut de hautes études internationales et du développement

Édition imprimée

Date de publication : 1 janvier 1981

Pagination : 237-251

ISSN : 1660-5934

Référence électronique

Richard Gerster, "La Suisse et le Fonds monétaire international : les intérêts en présence et le options politiques », Annuaire suisse de politique de développement [En ligne], 1 | 1981, mis en ligne le 21 janvier 2013, consulté le 10 décembre 2020. URL : http://journals.openedition.org/aspd/1107 ; DOI : https:// doi.org/10.4000/aspd. 1107

Ce document a été généré automatiquement le 10 décembre 2020.

(c) The Graduate Institute / Geneva 


\section{La Suisse et le Fonds monétaire international : les intérêts en présence et le options politiques}

Die Schweiz und der internationale Währungsfonds : Interessenlage und Entwicklungspolitische optionen

Richard Gerster

\section{NOTE DE L'ÉDITEUR}

En français, résumé seulement. Lire l'article original en allemand dans Schweizerisches Jahrbuch für Entwicklungspolitik : « Die Schweiz und der internationale Währungsfonds : Interessenlage und Entwicklungspolitische optionen », http://sjep.revues.org/926.

\section{RÉSUMÉS}

Dans cet article, l'auteur analyse les relations actuelles de la Suisse avec le Fonds monétaire international, relations que J. Witteveen, ancien directeur général du FMI, qualifia un jour de «non participation constructive ». Aujourd'hui, alors que la question de l'adhésion de la Suisse à cette institution est intensément discutée, l'article énonce les arguments en faveur d'une adhésion, et ceux qui s'y opposent, pour finalement conclure que, du point de vue de la politique de coopération au développement, l'adhésion serait recommandable à trois conditions :

- la Suisse devrait s'engager à œuvrer à modifier les conditions auxquelles sont accordées les facilités du Fonds monétaire international dans un sens qui tienne compte des besoins 
fondamentaux de la population et qui n'entraine pas de répression politique ;

- toute augmentation du quota de la Suisse au sein du Fonds monétaire international devrait être soumise à la ratification du Parlement ;

- tout accord éventuel de "stand-by" entre la Suisse et le Fonds monétaire international devrait être soumis au Parlement.

Sans devenir membre du Fonds monétaire international, la Suisse pourrait aussi œuvrer dans le même sens en modifiant la loi sur la Banque nationale de façon à ce que les mesures de politique monétaire ne soient pas en contradiction avec la loi fédérale sur la coopération au développement et l'aide humanitaire internationales. 